Article

\title{
Simulation Study on Reservoir Souring Induced by Injection of Reservoir Brine Containing Sulfate-Reducing Bacteria
}

\author{
Yuichi Sugai ${ }^{1, *}$, Yukihiro Owaki ${ }^{2}$ and Kyuro Sasaki ${ }^{1}$ \\ 1 Department of Earth Resources Engineering, Faculty of Engineering, Kyushu University, \\ Fukuoka 8190395, Japan; krsasaki@mine.kyushu-u.ac.jp \\ 2 Department of Earth Resources Engineering, Graduate School of Engineering, Kyushu University, \\ Fukuoka 8190395, Japan; o1o2wa3@yahoo.co.jp \\ * Correspondence: sugai@mine.kyushu-u.ac.jp; Tel.: +81-92-802-3328
}

Received: 18 April 2020; Accepted: 2 June 2020; Published: 4 June 2020

\begin{abstract}
This paper examined the reservoir souring induced by the sulfate-reducing bacteria (SRB) inhabiting the reservoir brine of an oilfield in Japan. Although the concentration of sulfate of the reservoir brine was lower than that of seawater, which often was injected into oil reservoir and induced the reservoir souring, the SRB inhabiting the reservoir brine generated hydrogen sulfide $\left(\mathrm{H}_{2} \mathrm{~S}\right)$ by using sulfate and an electron donor in the reservoir brine. This paper therefore developed a numerical simulator predicting the reservoir souring in the reservoir into which the reservoir brine was injected. The results of the simulation suggested that severe reservoir souring was not induced by the brine injection; however, the SRB grew and generated $\mathrm{H}_{2} \mathrm{~S}$ around the injection well where temperature was decreased by injected brine whose temperature was lower than that of formation water. In particular, $\mathrm{H}_{2} \mathrm{~S}$ was actively generated in the mixing zone between the injection water and formation water, which contained a high level of the electron donor. Furthermore, the results of numerical simulation suggested that the reservoir souring could be prevented more surely by sterilizing the SRB in the injection brine, heating up the injection brine to $50^{\circ} \mathrm{C}$, or reducing sulfate in the injection brine.
\end{abstract}

Keywords: reservoir souring; sulfate-reducing bacteria; sulfate; ethanol; hydrogen sulfide; reservoir brine; simulation; temperature propagation

\section{Introduction}

Reservoir souring is often induced by injecting seawater into an oil reservoir for secondary oil recovery because seawater often contains both sulfate and sulfate-reducing bacteria (SRB) which reduce sulfate and generate hydrogen sulfide $\left(\mathrm{H}_{2} \mathrm{~S}\right)$ in oil reservoirs using organic components as electron donors. Various organic matters such as formate, acetate, propionate, pyruvate, lactate, butyrate and ethanol can be the electron donors for SRB [1-9]. The mechanisms of reservoir souring caused by the injection of seawater have been reported by academic articles [10-13]; however, there has been no reports about reservoir souring induced by the injection of reservoir brine. The authors of this paper have studied on the reservoir souring in an oilfield in which the injection of reservoir brine is planned.

The concentration of sulfate in the reservoir brine of our target reservoir is as low as $0.63 \mathrm{mM}$, while that in seawater is $28 \mathrm{mM}$ approximately [14]. However, it was demonstrated that the SRB inhabiting the reservoir brine reduced sulfate and generate $\mathrm{H}_{2} \mathrm{~S}$ in the reservoir brine using ethanol as an electron donor in our previous study [15]. This result suggested that the reservoir souring could be also induced by the injection of reservoir brine which contained a low level of sulfate. Then, 
the authors of this paper have studied on the development of a numerical simulator evaluating the reservoir souring induced by the injection of brine water, which contains a low level of sulfate.

The reduction of sulfate was observed in not production water but injection water which were collected in the oilfield in our previous study [15]. Our previous study demonstrated that the SRB inhabiting the injection water of the oilfield reduced sulfate using ethanol as an electron donor and generated $\mathrm{H}_{2} \mathrm{~S}$. The following reaction was therefore assumed to occur in the reservoir into which the water containing the SRB was injected:

$$
\mathrm{C}_{2} \mathrm{H}_{5} \mathrm{OH}+\frac{1}{2} \mathrm{SO}_{4}^{2-} \rightarrow \mathrm{CH}_{3} \mathrm{COO}^{-}+\frac{1}{2} \mathrm{HS}^{-}+\frac{1}{2} \mathrm{H}^{+}+\mathrm{H}_{2} \mathrm{O} \text {. }
$$

We constructed the numerical models of the bacterial activities such as the growth of the SRB, consumption of sulfate and ethanol by the SRB, and generation of $\mathrm{H}_{2} \mathrm{~S}$ by the SRB inhabiting the injection water of the oilfield [15]. It was demonstrated that those numerical models could effectively simulate the bacterial activities which were observed in the injection water.

The purpose of this study is to develop a numerical simulator evaluating the reservoir souring induced by the injection of the reservoir brine by introducing the numerical models constructed in our previous study into a reservoir simulator. Various simulation studies on the biogenic reservoir souring have been reported by many authors. Delshad et al. [16] reported a numerical prediction of the biogenic reservoir souring using a chemical flooding simulator. They attached weight to the sensitivity of the reservoir souring to the reservoir conditions such as temperature propagation, pressure and heterogeneity in the reservoir, while the conditions relating to the metabolisms of SRB were not considered. Farhadinia et al. $[17,18]$ successfully predicted the reservoir souring using a chemical flooding simulator. Their model did not however consider the influence of temperature, salinity and $\mathrm{pH}$ on the activities of SRB. Alexandre et al. [19] also reported a simulation study on the reservoir souring; however, they did not also simulate the activities of SRB because they used a commercial reservoir simulator. In contrast, Hosseininoosheri et al. [20] and Evans et al. [21] developed the reservoir souring simulators, which included the models representing the activities of SRB. They constructed mathematical models of the growth of SRB based on the Monod equation containing the concentration of nutrients, temperature, salinity and $\mathrm{pH}$ as parameters. In addition, Sunde et al. [22] developed more detailed model considering the $\mathrm{H}_{2} \mathrm{~S}$ generation sites. They assumed that $\mathrm{H}_{2} \mathrm{~S}$ was generated by SRB in both mixing zone between injection water and formation water, and biofilm formed by SRB themselves. Those assumptions were not however revealed by experiments in their paper.

The reservoir souring simulators are extremely useful for not only predicting the reservoir souring but also for developing new technologies preventing reservoir souring. Coombe et al. [23] reported a technique controlling the biogenic reservoir souring by injecting nitrate into reservoir through the simulation study. Moreover, it is certain that the development of shale oil and gas will continue to advance in the future and new technologies injecting fluids into shale layers for enhancing oil and/or gas recovery have been suggested recently [24]. Because those technologies may however have a risk causing the biogenic souring in shale layers, the demand for the reservoir souring simulators will be also increased in shale field.

Dunsmore et al. [25] suggested that the simulator predicting the biogenic reservoir souring induced by the injection of seawater or reservoir brine. There have been however few papers reporting the simulation of the reservoir souring induced by reservoir brine injection, whereas a number of papers including papers described above reported the reservoir souring induced by seawater injection. Because seawater usually contains a high level of sulfate, SRB can easily grow and generate $\mathrm{H}_{2} \mathrm{~S}$ in the seawater-based culture medium. It is therefore easy to construct the mathematical models representing the activities of SRB using the results of the incubation experiments using seawater. On the other hand, it may be difficult to collect experimental data using reservoir brine in comparison with a case of seawater because reservoir brine contains a low level of sulfate.

The authors of this paper successfully constructed mathematical models representing the growth of the SRB and reduction of sulfate and generation of $\mathrm{H}_{2} \mathrm{~S}$ by the SRB in reservoir brine, which contained 
a low level of sulfate in our previous paper [15]. Those models were constructed in the basis of the Monod equation containing the concentration of nutrients and temperature as parameters. Salinity and $\mathrm{pH}$, which were contained in the models constructed by [17-22], were not contained as parameters in our models because those values should be similar between the injection brine and formation brine.

The purpose of this study is to develop a simulator predicting the biogenic reservoir souring induced by injecting the reservoir brine which contains a low level of sulfate by using the mathematical models which have been constructed by our previous study. Moreover, the present study clarifies the mechanisms of the biogenic reservoir souring induced by injecting the reservoir brine into a Japanese oil reservoir in which reservoir brine injection is now planned by using the simulator. Moreover, the biogenic reservoir souring in that oil reservoir was predicted through the numerical experiments using the simulator in this study.

\section{Materials and Methods}

\subsection{Mathematical Model of the Growth Rate of the SRB}

The growth of bacteria can be classified into four stages such as lag phase, logarithmic growth phase, stationary phase and death phase in general. According to our previous study [15], consumption of sulfate by the SRB was observed during only their logarithmic growth phase. Similar results were also shown by other papers [26-29], therefore, this study assumes that both consumption of sulfate and generation of $\mathrm{H}_{2} \mathrm{~S}$ were occurred during only the logarithmic growth phase of the SRB. Because the objective of this study is to evaluate the production of $\mathrm{H}_{2} \mathrm{~S}$ which is generated by the SRB in oil reservoir, it is enough to simulate only the logarithmic growth phase in which $\mathrm{H}_{2} \mathrm{~S}$ was generated by the SRB in this study.

In our numerical simulation, the SRB grow logarithmically and generate $\mathrm{H}_{2} \mathrm{~S}$ when they coexist with both sulfate and ethanol in a grid block of the reservoir model. When one of those nutrients is absent in a grid block, the SRB cannot grow any more in the grid block. The increase in bacterial cell number per micro time can be calculated by the Equation (2) [30].

$$
\frac{d x}{d t}=\mu x
$$

where $\mu$ is the specific growth rate $\left(\mathrm{h}^{-1}\right), x$ is bacterial cell number (cells) and $t$ is incubation time (h). The bacterial cell number at a time $t$ can be calculated by the Equation (3), which is obtained by integrating Equation (2) [30].

$$
x_{t}=x_{t-\Delta t} e^{\mu \Delta t}
$$

The specific growth rate of bacteria in the logarithmic growth phase can be calculated by the Monod equation, as shown by Equation (4) [31].

$$
\mu=\frac{\mu_{\mathrm{m}} C_{\text {Nutrient }}}{\left(K_{\text {Nutrient }}+C_{\text {Nutrient }}\right)}
$$

where $\mu_{\mathrm{m}}$ is the maximal growth rate $\left(\mathrm{h}^{-1}\right)$ obtained in excess nutrient, $K_{\text {Nutrient }}$ is the nutrient concentration corresponding to half of maximal growth rate $(\mathrm{g} / \mathrm{L})$, and $C_{\text {Nutrient }}(\mathrm{g} / \mathrm{L})$ is the concentration of growth limiting nutrient for bacteria. Both sulfate and ethanol were determined to be growth limiting nutrients for the SRB; therefore, the following two Monod equations which were a function of the concentration of sulfate and ethanol, respectively, were derived on the basis of the experimental results in our previous study [15].

$$
\begin{aligned}
\mu_{\text {Sulfate }} & =\frac{3.5 \times 10^{-3} C_{\text {Sulfate }}}{\left(7.8 \times 10^{-3}+C_{\text {Sulfate }}\right)} \\
\mu_{\text {Ethanol }} & =\frac{4.0 \times 10^{-2} C_{\text {Ethanol }}}{\left(6.9 \times 10^{-3}+C_{\text {Ethanol }}\right)}
\end{aligned}
$$


Incidentally, the other organic matters such as formate, acetate and propionate were also subjected to the experiments as candidates of the electron donors for the SRB in our previous study. It was however shown that the SRB did not use those organic matters as the electron donors; therefore, the effect of those organic matters on the activities of the SRB was neglected in this study.

Because temperature is different between reservoir and injection water, temperature distribution is assumed to be formed in the reservoir during the water flooding. According to our previous study [15], the specific growth rate of the SRB is also affected by temperature; therefore, the influence of temperature on the growth rate of the SRB was considered in the numerical simulation. A coefficient term representing the influence of temperature on the growth of the SRB was derived as shown by Equation (7) on the basis of the experimental results of our previous study [15].

$$
c_{\mathrm{T}}=e^{\left\{-1.7 \times 10^{-2} \times(T-50)^{2}\right\}}
$$

where $c_{\mathrm{T}}$ is the temperature coefficient term (non-dimension) and $T$ is temperature $\left({ }^{\circ} \mathrm{C}\right)$. Finally, the specific growth rate of the SRB in the reservoir was derived as the geometric mean of Equations (5) and (6) multiplied by the temperature coefficient term.

$$
\mu_{\mathrm{SRB}}=\sqrt{\mu_{\text {Sulfate }} \times \mu_{\text {Ethanol }}} \times c_{\mathrm{T}}
$$

\subsection{Mathematical Model of the Consumption Rate of the Nutrients and Generation of $\mathrm{H}_{2} \mathrm{~S}$ by the SRB}

The SRB was assumed to consume sulfate and ethanol during only their logarithmic growth phase in our previous study [15]. The amount of sulfate at a time $t$ can be calculated by the Equation (9).

$$
S_{t}=S_{t-\Delta t}-\frac{x_{t}-x_{t-\Delta t}}{Y}
$$

where $S_{t}$ is the amount of sulfate (g) at a time $t, x_{t}$ is the bacterial cell number (cells) at a time $t$, and $Y$ is the growth yield (cells/g). Assuming that sulfate is completely consumed at the end of the logarithmic growth phase of the SRB, the growth yield can be calculated by Equation (10).

$$
Y=\frac{x_{\mathrm{m}}-x_{0}}{S_{0}}
$$

where $x_{\mathrm{m}}$ is the maximal number of the bacterial cell in culture solution (cells), $x_{0}$ is the initial bacterial cell number (cell) and $S_{0}$ is the initial amount of sulfate $(\mathrm{g})$. Because the growth yield was varied with the concentration of sulfate, the equation calculating the growth yield was derived as a function of the concentration of sulfate as shown by Equation (11) [15].

$$
Y=\frac{1.3 \times 10^{13}}{\left\{1+\left(\frac{C_{\text {Sulfate }}-0.026}{0.040}\right)^{2}\right\}}+1.4 \times 10^{12}
$$

Both the decrease in ethanol and increase in $\mathrm{H}_{2} \mathrm{~S}$ can be decided automatically by the decrease in sulfate on the basis of the reaction in Equation (1).

\subsection{Material Balance Equation}

Numerical simulation studies were carried out to evaluate the $\mathrm{H}_{2} \mathrm{~S}$ generation in an oil reservoir during the water flooding on quarter of a five-spot pattern flooding. The numerical model which was constructed in this study consisted of two phases (oil and water) and six components (oil, water, $\mathrm{SRB}$, nutrients and metabolite). The nutrients for the SRB were sulfate and ethanol. The metabolite of the SRB was $\mathrm{H}_{2} \mathrm{~S}$. We assumed that $\mathrm{H}_{2} \mathrm{~S}$ which was generated by the SRB was completely dissolved into only water in oil reservoir and flowed in reservoir as a component of water phase in this study. In addition, we did not consider the adsorption of microorganism, nutrients and dissolved $\mathrm{H}_{2} \mathrm{~S}$ on to the rock surface in order to simply examine the behavior of $\mathrm{H}_{2} \mathrm{~S}$ generation in oil reservoir caused 
by the SRB. We also neglected the diffusion of those components in the water phase because their diffusion was small enough to neglect it on the field scale simulation.

The flow equations for oil and water are given by Equations (12) and (13), respectively.

$$
\begin{gathered}
\alpha \frac{\partial\left(\varnothing S_{\mathrm{o}} \rho_{\mathrm{o}}\right)}{\partial t}=\nabla\left(\alpha \frac{k_{\mathrm{o}}}{\mu_{\mathrm{o}}} \rho_{\mathrm{o}} \nabla \Phi_{\mathrm{o}}\right)-\alpha q_{\mathrm{op}} \\
\alpha \frac{\partial\left(\varnothing S_{\mathrm{w}} \rho_{\mathrm{w}}\right)}{\partial t}=\nabla\left(\alpha \frac{k_{\mathrm{w}}}{\mu_{\mathrm{w}}} \rho_{\mathrm{w}} \nabla \Phi_{\mathrm{w}}\right)-\alpha\left(q_{\mathrm{wi}}-q_{\mathrm{w} p}\right)
\end{gathered}
$$

where $\alpha$ is the dimensional constant number, $\varphi$ is porosity, $S_{\mathrm{o}}$ and $S_{\mathrm{w}}$ are saturation of oil and water, respectively, $\rho_{\mathrm{o}}$ and $\rho_{\mathrm{w}}$ are density of oil and water, respectively, $k_{\mathrm{o}}$ and $k_{\mathrm{w}}$ are effective permeability of oil and water, $\mu_{\mathrm{o}}$ and $\mu_{\mathrm{w}}$ are viscosity of oil and water, respectively, $\Phi_{\mathrm{o}}$ and $\Phi_{\mathrm{w}}$ are the flow potential of oil and water, respectively, $q_{\mathrm{wi}}, q_{\mathrm{wp}}$ and $q_{\mathrm{op}}$ are injection rate of water, production rate of water and production rate of oil, respectively. The transports of SRB, nutrients and metabolite are described by Equations (14)-(16).

$$
\begin{gathered}
\alpha \frac{\partial\left(\varnothing S_{\mathrm{w}} \rho_{\mathrm{w}} C_{\mathrm{SRB}}\right)}{\partial t}=\nabla\left(\alpha \frac{k_{\mathrm{w}}}{\mu_{\mathrm{w}}} \rho_{\mathrm{w}} C_{\mathrm{SRB}} \nabla \Phi_{\mathrm{w}}\right)+\alpha\left\{\rho_{\mathrm{w}} R_{\mathrm{SRB}}+C_{\mathrm{SRB}}\left(q_{\mathrm{wi}}-q_{\mathrm{w} p}\right)\right\} \\
\alpha \frac{\partial\left(\varnothing S_{\mathrm{w}} \rho_{\mathrm{w}} C_{\text {Nutrient }}\right)}{\partial t}=\nabla\left(\alpha \frac{k_{\mathrm{w}}}{\mu_{\mathrm{w}}} \rho_{\mathrm{w}} C_{\text {Nutrient }} \nabla \Phi_{\mathrm{w}}\right)-\alpha\left\{\rho_{\mathrm{w}} R_{\text {Nutrient }}-C_{\text {Nutrient }}\left(q_{\mathrm{wi}}-q_{\mathrm{w} p}\right)\right\} \\
\alpha \frac{\partial\left(\varnothing S_{\mathrm{w}} \rho_{\mathrm{w}} C_{\mathrm{H}_{2} \mathrm{~S}}\right)}{\partial t}=\nabla\left(\alpha \frac{k_{\mathrm{w}}}{\mu_{\mathrm{w}}} \rho_{\mathrm{w}} C_{\mathrm{H}_{2} \mathrm{~S}} \nabla \Phi_{\mathrm{w}}\right)+\alpha\left\{\rho_{\mathrm{w}} R_{\mathrm{H}_{2} \mathrm{~S}}+C_{\mathrm{H}_{2} \mathrm{~S}}\left(q_{\mathrm{wi}}-q_{\mathrm{w} p}\right)\right\}
\end{gathered}
$$

where $C_{\mathrm{SRB}}, C_{\text {Nutrient }}$ and $\mathrm{C}_{\mathrm{H} 2 \mathrm{~S}}$ are concentration of SRB, a nutrient (sulfate or ethanol) and $\mathrm{H}_{2} \mathrm{~S}$ in water, respectively, $R_{\mathrm{SRB}}, R_{\mathrm{Nutrient}}$ and $R_{\mathrm{H} 2 \mathrm{~S}}$ are the growth rate of $\mathrm{SRB}$, consumption rate of a nutrient (sulfate or ethanol) by the SRB, and Generation rate of $\mathrm{H}_{2} \mathrm{~S}$ by the $\mathrm{SRB}$, respectively.

\subsection{Validity of the Model Used in This Study}

The validity of the models representing the growth of the SRB, reduction of sulfate, and generation of $\mathrm{H}_{2} \mathrm{~S}$ by the SRB was shown in our previous paper [15]. Those behaviors which had been observed in the incubation experiments were well simulated by the models. The validity of the models representing the flow of components in reservoir was also shown in the previous study. The current model is originated from the model which had been previously constructed for the simulation study on the Microbial Enhanced Oil Recovery (MEOR) by an author of this paper [32]. The validity of the original model had been successfully shown through the history matching between the numerical results and experimental results of a core flooding experiment. Because the validity of the original model had been already confirmed, the validity of the current model can be also assumed to be guaranteed.

\subsection{Reservoir Model Used in the Numerical Simulation}

The numerical simulation studies were carried out to examine the behavior of $\mathrm{H}_{2} \mathrm{~S}$ generation in oil reservoir during the water flooding on quarter of a five-spot pattern flooding. The reservoir model, reservoir conditions and conditions for the water injection are shown in Table 1 . The reservoir model used in this study was $360 \mathrm{~m}$ length, $360 \mathrm{~m}$ width and $1 \mathrm{~m}$ thick. As described at the beginning of the next chapter, the effect of the grid size on the simulation results was examined and it was decided that the reservoir model was discretized into $36 \times 36$ uniform grid blocks in the $x$ and $y$ directions and a one $1 \mathrm{~m}$ thick grid block in the $z$ direction in this study. Absolute permeability and porosity of the reservoir was $10 \mathrm{md}$ and $20 \%$, respectively. Because this study assumes water flooding in a mature oilfield, water saturation was set to a high value such as $62.5 \%$.

We assumed that the water whose temperature was $40{ }^{\circ} \mathrm{C}$ was injected into oil reservoir whose original temperature was $100^{\circ} \mathrm{C}$. The temperature distribution was therefore formed by the water 
injection whose temperature was lower than the original temperature of the reservoir. The growth of the $\mathrm{SRB}$ and $\mathrm{H}_{2} \mathrm{~S}$ generation by them was assumed to be influenced by the temperature distribution. We therefore examined the sensitivity of the temperature distribution to $\mathrm{H}_{2} \mathrm{~S}$ generation by the SRB in the reservoir in this study. Figure 1 shows the temperature distributions which were set up for this study. A numerical simulator STARS (CMG, Canada) was used for obtaining the temperature distributions. The temperature distributions in the reservoir was obtained by injecting water whose temperature was $40{ }^{\circ} \mathrm{C}$ into a reservoir whose temperature was $100{ }^{\circ} \mathrm{C}$ with the injection rate of 5.33 $\mathrm{m}^{3} /$ day for (a) 6 years or (b) 2 years on the simulator. The reservoirs which have the temperature distributions shown by Figure 1a,b are called reservoir A and B, respectively, in this paper.

Table 1. Calculation conditions of the numerical simulation of this study.

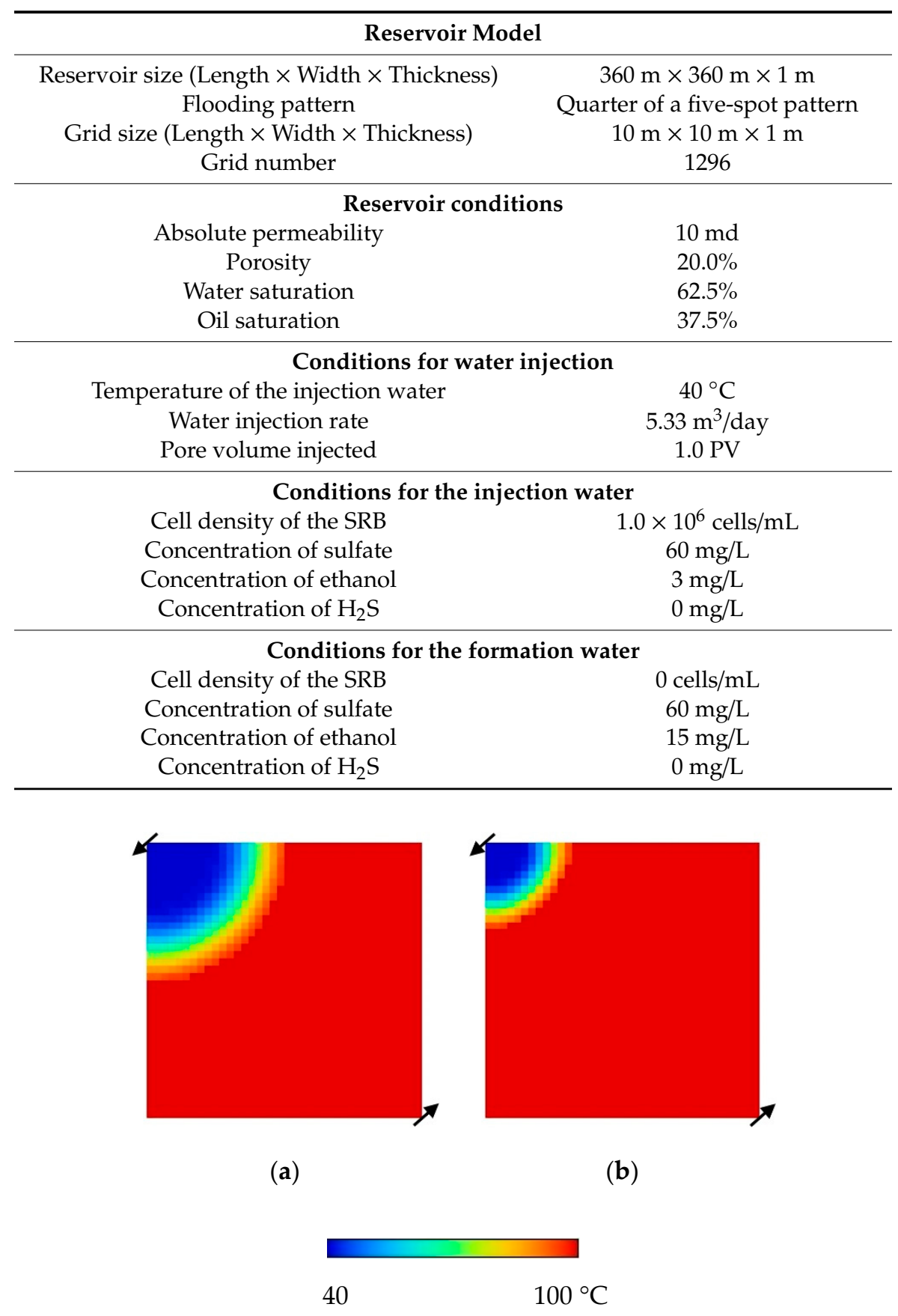

Figure 1. Temperature distribution of (a) reservoir A and (b) reservoir B used in this study. 


\subsection{The Calculation Flow of the Simulation}

The conditions of injection water and formation water are shown in Table 1. Those conditions were set based on the conditions of a real oilfield in Japan. This study assumed that the SRB inhabited the injection water at a concentration of $1.0 \times 10^{6}$ cells $/ \mathrm{mL}$ while they did not inhabit the formation water. The bacterial concentration was set based on the real data which had been quantified by a DNA based method, real-time PCR in our previous study [15]. Concentrations of sulfate, ethanol and $\mathrm{H}_{2} \mathrm{~S}$ in the injection water were $60 \mathrm{mg} / \mathrm{L}, 3 \mathrm{mg} / \mathrm{L}$ and $0 \mathrm{mg} / \mathrm{L}$, respectively, while their concentrations in the formation water were $60 \mathrm{mg} / \mathrm{L}, 15 \mathrm{mg} / \mathrm{L}$ and $0 \mathrm{mg} / \mathrm{L}$, respectively. SRB start to grow and generate $\mathrm{H}_{2} \mathrm{~S}$ when they coexist with both sulfate and ethanol in a same grid block. The growth of the SRB is stopped if one of them is missing in a grid block. $\mathrm{H}_{2} \mathrm{~S}$ which is generated by the SRB in reservoir dissolves in water completely and flows together with water in the reservoir.

\section{Results and Discussion}

\subsection{Consideration of the Mechanisms of $\mathrm{H}_{2} \mathrm{~S}$ Generation in the Reservoir}

The mechanism of $\mathrm{H}_{2} \mathrm{~S}$ generation in the reservoir $\mathrm{A}$ is discussed by examining the distribution of the cell density of the SRB and the concentration of sulfate, ethanol and $\mathrm{H}_{2} \mathrm{~S}$ in the reservoir during the water flooding in this section.

Figure 2a shows the contour maps of the cell density of the SRB in the reservoir during the water flooding. The cell density of the SRB within a radius of $90 \mathrm{~m}$ from the injection well was still less than $1.0 \times 10^{8}$ cells $/ \mathrm{mL}$ after 0.05 pore volume (PV) of water was injected into the reservoir. The growth of the SRB was still in the early logarithmic growth phase in this area at this stage. The highest cell density of the SRB was observed between a radius of $90 \mathrm{~m}$ and $160 \mathrm{~m}$ and the logarithmic growth phase was completed in this area at this stage. Both sulfate and ethanol were consumed and $\mathrm{H}_{2} \mathrm{~S}$ was actively generated within that area as shown in Figure $2 \mathrm{~b}-\mathrm{d}$. According to the temperature distribution shown in the Figure 1, temperature of this area was less than $50^{\circ} \mathrm{C}$; therefore, the SRB was able to grow and generate $\mathrm{H}_{2} \mathrm{~S}$ in this area.

Because concentration of ethanol in the formation water was higher than that in the injection water, growth of the SRB, consumption of sulfate and ethanol, and generation of $\mathrm{H}_{2} \mathrm{~S}$ were further activated in the mixing zone between formation water and injection water. This mechanism was also suggested by $[21,22]$. On the other hand, those bacterial activities were not found in the area whose temperature was over $50^{\circ} \mathrm{C} . \mathrm{H}_{2} \mathrm{~S}$ which had been generated around the injection well flowed to the production well and it began to be produced from the production well after $0.6 \mathrm{PV}$ of water injection.

Next, the influence of temperature distribution in the reservoir on the $\mathrm{H}_{2} \mathrm{~S}$ generation by the SRB is discussed in this section. Because the low temperature area around the injection well in the reservoir $B$ was smaller than that in the reservoir A, the area in which the SRB could grow in the reservoir B was also smaller than that in the reservoir A (data not shown). $\mathrm{H}_{2} \mathrm{~S}$ was therefore generated in such small area only in the reservoir B, as shown in Figure 3.

Figure 4 shows the $\mathrm{H}_{2} \mathrm{~S}$ concentration in the water produced from both reservoirs. $\mathrm{H}_{2} \mathrm{~S}$ was started to be detected in the production water 2200 days after the injection was started. The maximum concentration of $\mathrm{H}_{2} \mathrm{~S}$ in the water produced from the reservoir A was approximately $1.2 \mathrm{mg} / \mathrm{L}$; in other words, $800 \mathrm{~mL}$ of $\mathrm{H}_{2} \mathrm{~S}$ under the normal temperature and pressure conditions was produced as an associated gas with $1 \mathrm{~kL}$ of the reservoir brine from the reservoir $\mathrm{A}$. It was shown that the reservoir souring was induced by the injection of reservoir brine whose sulfate concentration was quite low, although the amount of $\mathrm{H}_{2} \mathrm{~S}$ associating with the production fluids was not very large.

The time period when the $\mathrm{H}_{2} \mathrm{~S}$ production begun in the reservoir $\mathrm{B}$ was delayed by approximately 400 days compared to that period in the reservoir A. Moreover, the maximum concentration of $\mathrm{H}_{2} \mathrm{~S}$ in the water produced from the reservoir B was approximately $0.8 \mathrm{mg} / \mathrm{L}$ which was $30 \%$ lower than that from the reservoir A. These results suggest that the injection of water whose temperature is $50^{\circ} \mathrm{C}$ or above is effective for preventing $\mathrm{H}_{2} \mathrm{~S}$ generation in the reservoir because the SRB inhabiting the 
injection water used in this study can only grow in temperatures that are under $50{ }^{\circ} \mathrm{C}$. The heat which is exhausted from surface facilities in oilfield can be utilized for heating the injection water more than $50{ }^{\circ} \mathrm{C}$ for example. The temperature distribution of the reservoir $\mathrm{B}$ was used in the following sections.

3.2. Consideration of the Influence of the Concentration of the SRB and/or Sulfate in the Injection Water on the $\mathrm{H}_{2} \mathrm{~S}$ Generation

The influence of the concentration of the SRB and/or sulfate in the injection water on the $\mathrm{H}_{2} \mathrm{~S}$ generation in the reservoir $B$ is discussed in this section. The cell density of the SRB in the injected water was set to $1.0 \times 10^{5}$ cells $/ \mathrm{mL}$ or $1.0 \times 10^{4}$ cells $/ \mathrm{mL}$, while all other conditions were fixed to the standard conditions which were shown in Table 1 in order to examine the influence of the cell density of the SRB in the injected water on the $\mathrm{H}_{2} \mathrm{~S}$ generation in the reservoir. Also, the concentration of sulfate in the injected water was set to $40 \mathrm{mg} / \mathrm{L}$ or $20 \mathrm{mg} / \mathrm{L}$, while all other conditions were fixed to the standard conditions in order to examine the influence of the concentration of sulfate in the injected water on the $\mathrm{H}_{2} \mathrm{~S}$ generation in the reservoir.

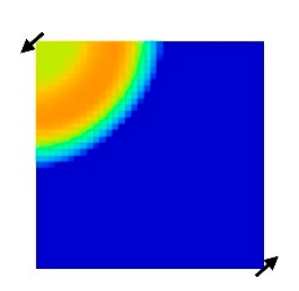

$0.05 \mathrm{PV}$

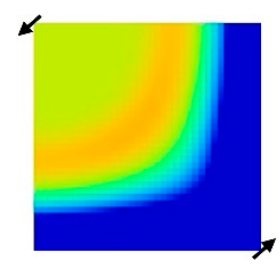

$0.3 \mathrm{PV}$

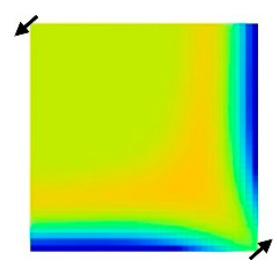

$0.6 \mathrm{PV}$

$10^{5}$

$10^{9}$ cells $/ \mathrm{mL}$

(a) Cell density of the SRB

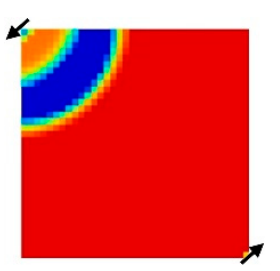

$0.05 \mathrm{PV}$

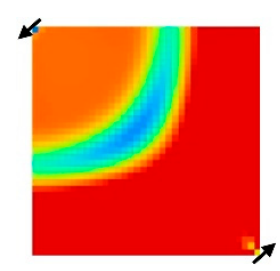

$0.3 \mathrm{PV}$

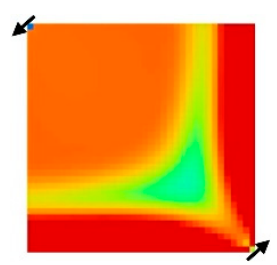

0.6 PV

50

$60 \mathrm{mg} / \mathrm{L}$

(b) Concentration of sulfate

Figure 2. Cont. 


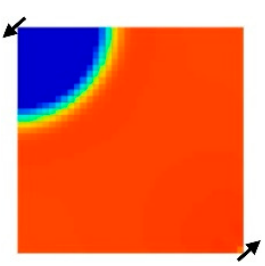

$0.05 \mathrm{PV}$

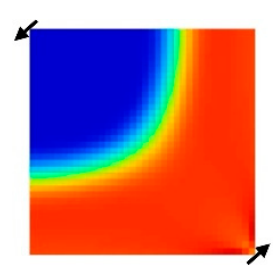

$0.3 \mathrm{PV}$

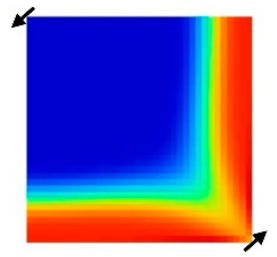

0.6 PV

0.1

$16.5 \mathrm{mg} / \mathrm{L}$

(c) Concentration of ethanol

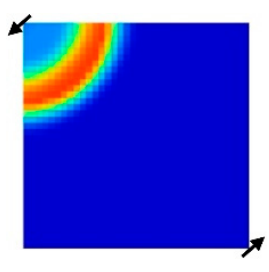

0.05 PV

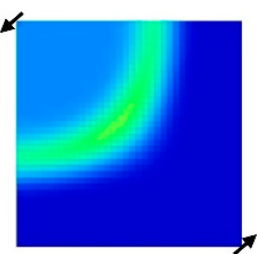

0.3 PV

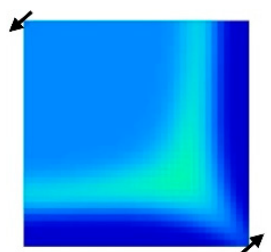

0.6 PV

0

$$
6 \mathrm{mg} / \mathrm{L}
$$

(d) Concentration of $\mathrm{H}_{2} \mathrm{~S}$

Figure 2. Contour maps of (a) cell density of SRB, (b) concentration of sulfate, (c) concentration of ethanol and (d) concentration of $\mathrm{H}_{2} \mathrm{~S}$ in the reservoir A during the water flooding.

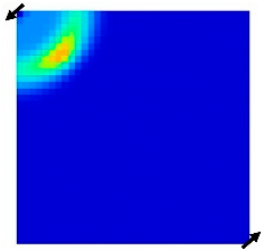

$0.05 \mathrm{PV}$

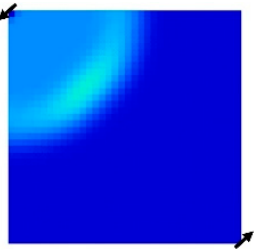

$0.3 \mathrm{PV}$

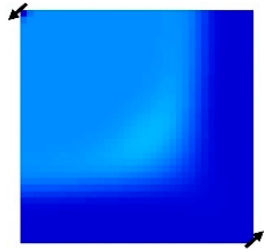

0.6 PV

0

$$
6 \mathrm{mg} / \mathrm{L}
$$

Figure 3. Contour maps of the concentration of $\mathrm{H}_{2} \mathrm{~S}$ in the reservoir $\mathrm{B}$ during the water flooding.

Figure 5 shows the concentration of $\mathrm{H}_{2} \mathrm{~S}$ in the water produced from the reservoir $\mathrm{B}$ into which water containing the SRB and/or sulfate with different concentration was injected. Those results suggest that those factors did not influence the $\mathrm{H}_{2} \mathrm{~S}$ generation by the SRB in the reservoir. The SRB which was injected into the reservoir could easily grow and generate $\mathrm{H}_{2} \mathrm{~S}$ in the reservoir, even if its concentration in the injection water was low. The SRB inhabiting the injection water must be therefore sterilized completely to prevent the $\mathrm{H}_{2} \mathrm{~S}$ generation in the reservoir. It is however practically impossible to sterilize them completely in the field, and the incomplete sterilization of the injection water is ineffective for preventing the $\mathrm{H}_{2} \mathrm{~S}$ generation. In addition, SRB injected into the reservoir 
can grow and generate $\mathrm{H}_{2} \mathrm{~S}$ using sulfate exiting the reservoir brine; therefore, it is also ineffective in removing sulfate from the injection water to prevent the $\mathrm{H}_{2} \mathrm{~S}$ generation in a reservoir.

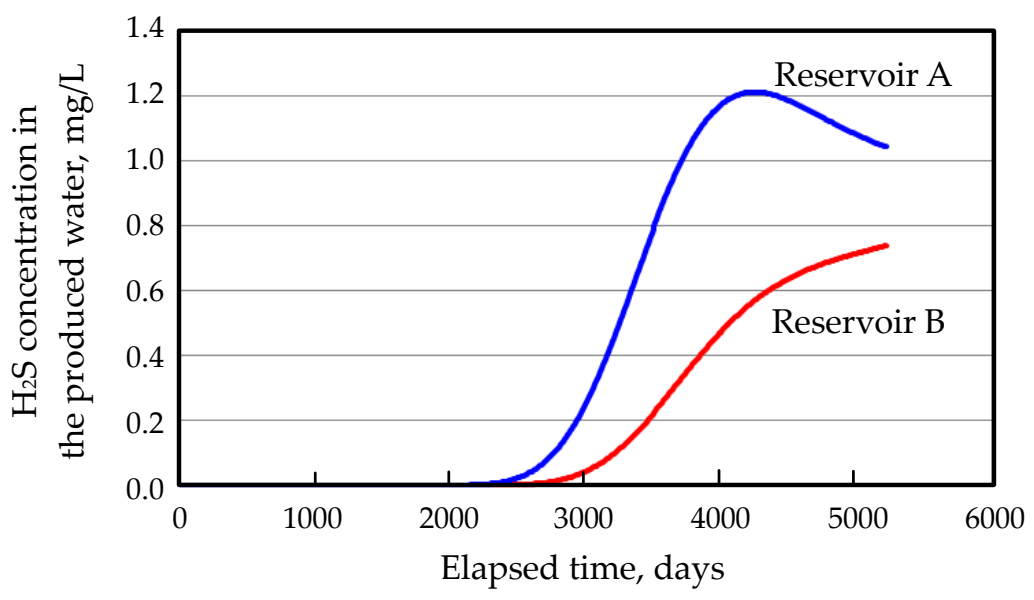

Figure 4. $\mathrm{H}_{2} \mathrm{~S}$ concentration in the water produced from both reservoirs.

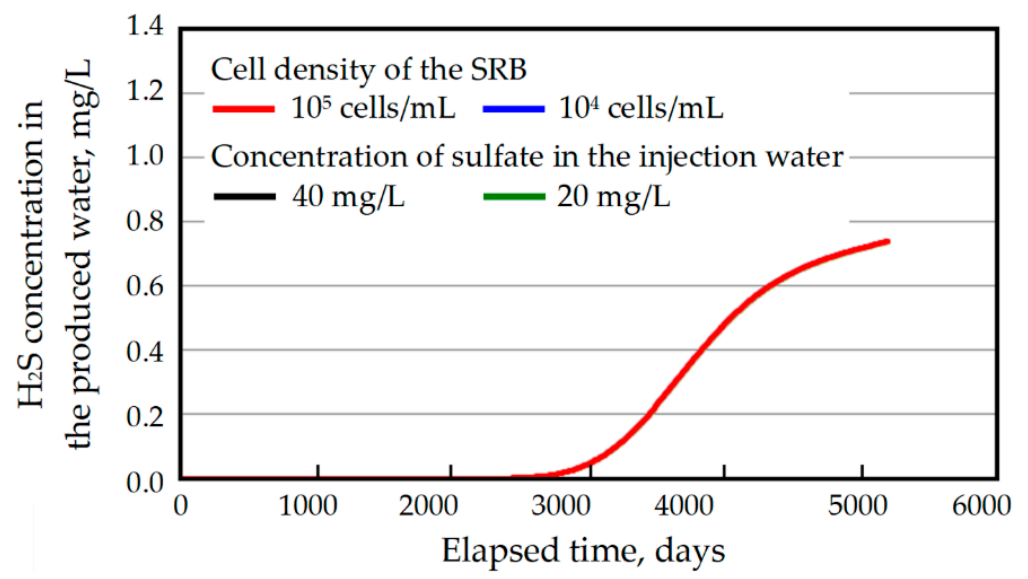

Figure 5. $\mathrm{H}_{2} \mathrm{~S}$ concentration in the water produced from reservoirs into which the water containing the $\mathrm{SRB}$ and sulfate in each different concentration. (All the results were close to each other.).

\subsection{Consideration of the Influence of Ethanol Concentration in the Injection Water and/or Formation Water on} the $\mathrm{H}_{2} \mathrm{~S}$ Generation

The influence of the concentration of ethanol in the injection water and/or formation water on the $\mathrm{H}_{2} \mathrm{~S}$ generation in the reservoir $\mathrm{B}$ is discussed in this section.

The concentration of ethanol in the injected water was set to $0 \mathrm{mg} / \mathrm{L}$, while all other conditions were fixed to the standard conditions in order to examine the influence of ethanol concentration in the injected water on the $\mathrm{H}_{2} \mathrm{~S}$ generation in the reservoir. Also, the concentration of ethanol in the formation water was set to $45 \mathrm{mg} / \mathrm{L}, 30 \mathrm{mg} / \mathrm{L}$ and $15 \mathrm{mg} / \mathrm{L}$, while all other conditions were fixed to the standard conditions in order to examine the influence of ethanol concentration in the formation water on the $\mathrm{H}_{2} \mathrm{~S}$ generation in the reservoir.

Figure 6 shows the concentration of $\mathrm{H}_{2} \mathrm{~S}$ in the water produced from the reservoir $\mathrm{B}$, into which water not containing ethanol was injected. The concentration of ethanol in the injection water influenced $\mathrm{H}_{2} \mathrm{~S}$ generation by the SRB in the reservoir. If ethanol can be completely removed from the injection water, $\mathrm{H}_{2} \mathrm{~S}$ concentration in the produced water can be decreased to half or less than that in the water produced from the reservoir into which water containing ethanol has been injected. 


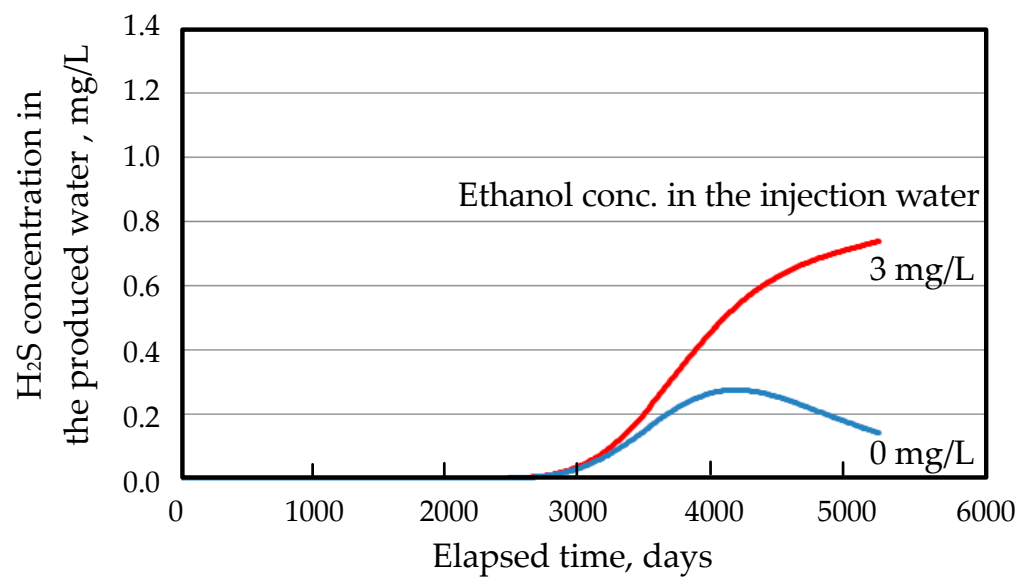

Figure 6. $\mathrm{H}_{2} \mathrm{~S}$ concentration in the water produced from reservoir into which water not containing ethanol was injected.

Because the concentration of ethanol in the formation water is an uncertain factor, the influence of that was examined through the numerical simulation with different ethanol concentration in this study. Figure 7 shows the concentration of $\mathrm{H}_{2} \mathrm{~S}$ in the water which was produced from reservoirs containing ethanol with different concentration. The concentration of $\mathrm{H}_{2} \mathrm{~S}$ in the produced water increased with the increase in the concentration of ethanol in the formation water. Ethanol concentration in the formation water is an influential factor in the $\mathrm{H}_{2} \mathrm{~S}$ generation in the reservoir; therefore, it is important to know the correct concentration of ethanol in the reservoir to precisely estimate the generation of $\mathrm{H}_{2} \mathrm{~S}$.

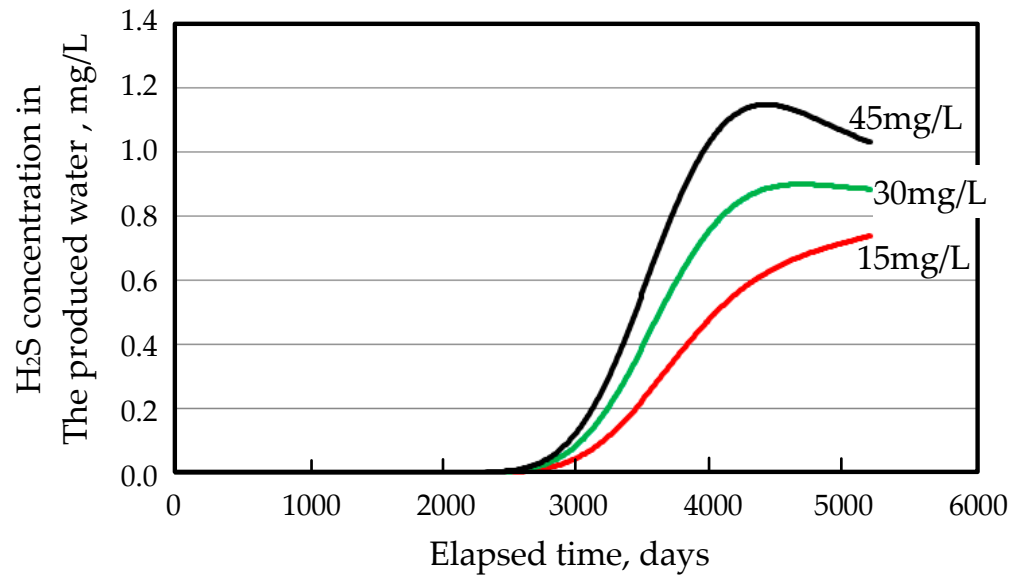

Figure 7. $\mathrm{H}_{2} \mathrm{~S}$ concentration in the water produced from reservoirs which contained ethanol with different concentration.

\subsection{Consideration of the Influence of Calculation Condition and Reservoir Condition on the $\mathrm{H}_{2} \mathrm{~S}$ Production}

The influence of calculation condition and reservoir condition on the $\mathrm{H}_{2} \mathrm{~S}$ production in the reservoir B is discussed in this section. The influence of grid number of the reservoir model on the simulation results was considered as a calculation condition in this section. The permeability heterogeneity of the reservoir has been suggested to affect fluids flow in reservoir [33,34]; therefore, the influence of the permeability heterogeneity on the simulation results was also examined as an important reservoir condition in this section.

Figure 8 shows the $\mathrm{H}_{2} \mathrm{~S}$ concentration in the water produced from reservoir $\mathrm{B}$ which was discretized into $18 \times 18,24 \times 24,30 \times 30$ and $36 \times 36$ uniform grid blocks in the $x$ and $y$ directions respectively and a one $1 \mathrm{~m}$ thick grid block in the $z$ direction. The grid size of those grid blocks was 20 square meters, 15 square meters, 12 square meters and 10 square meters, respectively. In the case of simulation with 
the largest grid size ( $20 \mathrm{~m}$ square), $\mathrm{H}_{2} \mathrm{~S}$ began to be detected earlier in the water produced than in the other three cases. $\mathrm{H}_{2} \mathrm{~S}$ began to be detected in the production water at a same time in other three cases; however, the production rate of $\mathrm{H}_{2} \mathrm{~S}$ in the case of the second largest grid size (15 m square) was lower than the other two cases. The behavior of $\mathrm{H}_{2} \mathrm{~S}$ production of the other two cases $(12 \mathrm{~m}$ square and $10 \mathrm{~m}$ square) was almost the same. From these results, we assumed that the simulation results converged towards a similar result by using the grid block whose size was less than 12 square meters.

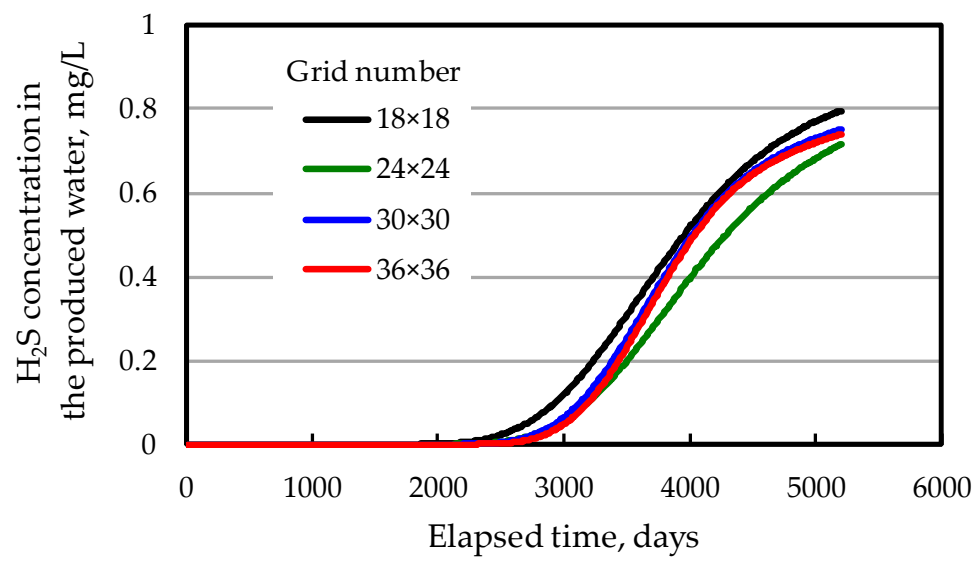

Figure 8. $\mathrm{H}_{2} \mathrm{~S}$ concentration in the water produced from reservoirs which had different grid numbers.

Figure 9 shows (a) permeability distribution and (b) temperature distribution of the heterogenous reservoir model used in this study. Because location of injection wells and production wells is usually designed to prevent them from connecting by high permeable channels, the lowest permeable zone was put into the shortest path between the injection well and production well. Then, the permeability gradually increased with distance from the shortest path, as shown in Figure 9a. As in the case of the simulation with the homogenous model, the temperature distributions in the heterogenous reservoir was obtained by injecting water whose temperature was $40^{\circ} \mathrm{C}$ into the reservoir whose temperature was $100{ }^{\circ} \mathrm{C}$ with the injection rate of $5.33 \mathrm{~m}^{3} /$ day for 2 years.

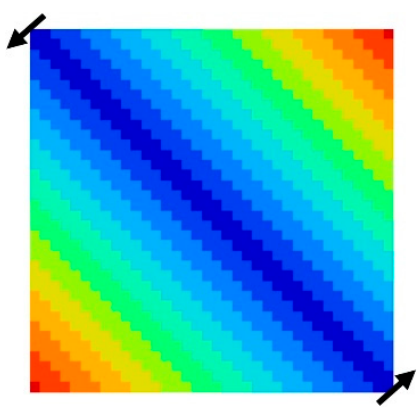

(a)

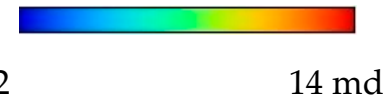

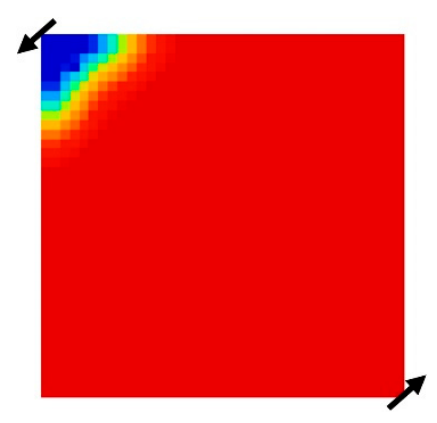

(b)

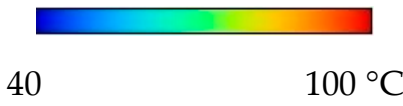

Figure 9. Permeability distribution (a) and temperature distribution (b) of the heterogenous reservoir model used in this study.

The flow behavior of $\mathrm{H}_{2} \mathrm{~S}$ in the heterogenous reservoir was quite different from that in the homogenous reservoir, which was shown in Figure 3. Because $\mathrm{H}_{2} \mathrm{~S}$, which had been generated in the low temperature area, preferentially bypassed the high permeable area as shown in Figure 10, the time period when the $\mathrm{H}_{2} \mathrm{~S}$ production begun in the heterogenous reservoir was delayed by approximately 
600 days compared to that period in the homogenous reservoir as shown in Figure 11. Thus, $\mathrm{H}_{2} \mathrm{~S}$ is generated in the low temperature area in the reservoir regardless of the permeability heterogeneity; however, the behavior of $\mathrm{H}_{2} \mathrm{~S}$ production from reservoir is affected by the heterogeneity. It is therefore important to consider the permeability heterogeneity of reservoir when predicting the reservoir souring.

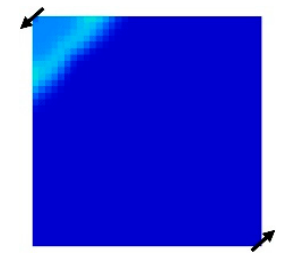

$0.05 \mathrm{PV}$

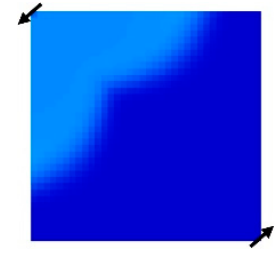

$0.3 \mathrm{PV}$

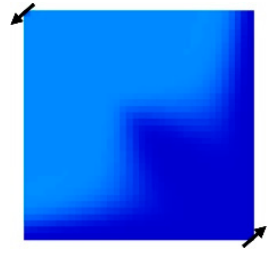

$0.6 \mathrm{PV}$

$$
0 \quad 6 \mathrm{mg} / \mathrm{L}
$$

Figure 10. Contour maps of the concentration of $\mathrm{H}_{2} \mathrm{~S}$ in the heterogenous reservoir during the water flooding.

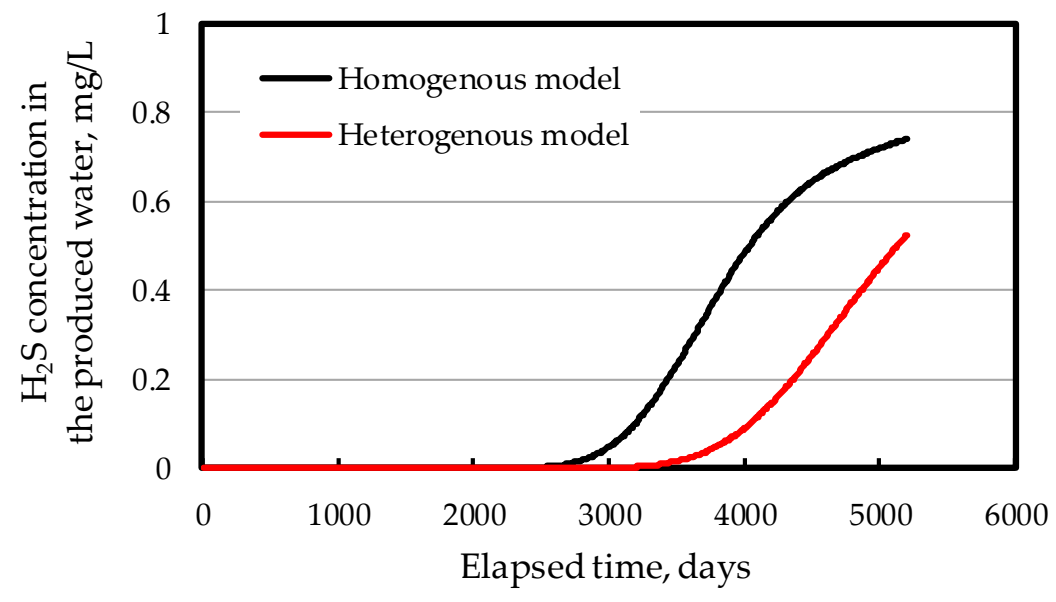

Figure 11. $\mathrm{H}_{2} \mathrm{~S}$ concentration in the water produced from heterogenous reservoirs and homogenous reservoir.

\subsection{Discussion about Sensitivity of the Simulation Results to the Assumptions}

Finally, the sensitivity of the simulation results to the assumptions used in this study is discussed in this section. The sensitivity is discussed with two indices as shown in Table 2: the time until start of $\mathrm{H}_{2} \mathrm{~S}$ production and the maximum concentration of $\mathrm{H}_{2} \mathrm{~S}$ in the water produced from the production well.

The simulation results were the most sensitive to the temperature distribution because a large difference in both indices was observed between two reservoir models which had different temperature distributions. The simulation results were the second most sensitive to the concentration of ethanol in the injection water and the formation water. In particular, the maximum concentration of $\mathrm{H}_{2} \mathrm{~S}$ was the most sensitive to the concentration of ethanol in the injection water while the time until start of $\mathrm{H}_{2} \mathrm{~S}$ production was not sensitive to that assumption. The time until the start of $\mathrm{H}_{2} \mathrm{~S}$ production was sensitive to the permeability heterogeneity and the grid number. That time may become shorter or longer depending on the heterogeneity. The maximum concentration of $\mathrm{H}_{2} \mathrm{~S}$ in the water produced from the heterogenous reservoir can be estimated to be similar to that from the homogenous reservoir because symmetric heterogeneity was set in this study. That value may be varied depending on the pattern of heterogeneity. The simulation results were not sensitive to the other factors in this study. 
Table 2. Summary of the simulation results with the two indices.

\begin{tabular}{|c|c|c|c|}
\hline Assumptions & Conditions & $\begin{array}{l}\text { Time Until Start of } \mathrm{H}_{2} \mathrm{~S} \\
\text { Production from the } \\
\text { Production Well, Days }\end{array}$ & $\begin{array}{c}\text { Maximum Concentration } \\
\text { of } \mathrm{H}_{2} \mathrm{~S} \text { in the Produced } \\
\text { Water, } \mathrm{mg} / \mathrm{L}\end{array}$ \\
\hline \multicolumn{4}{|c|}{ Reservoir Conditions } \\
\hline \multirow{2}{*}{$\begin{array}{l}\text { Temperature } \\
\text { distribution }\end{array}$} & Reservoir A & 2200 & 1.20 \\
\hline & Reservoir B & 2600 & $0.80 *$ \\
\hline \multirow{3}{*}{$\begin{array}{l}\text { Concentration of } \\
\text { ethanol }\end{array}$} & $15 \mathrm{mg} / \mathrm{L}$ & 2600 & $0.80 *$ \\
\hline & $30 \mathrm{mg} / \mathrm{L}$ & 2600 & 0.90 \\
\hline & $45 \mathrm{mg} / \mathrm{L}$ & 2600 & 1.13 \\
\hline \multirow{2}{*}{$\begin{array}{l}\text { Permeability } \\
\text { heterogeneity }\end{array}$} & Homogenous & 2600 & $0.80 *$ \\
\hline & Heterogenous & 3200 & $0.80 *$ \\
\hline \multicolumn{4}{|c|}{ Conditions of the Injection Water } \\
\hline \multirow{3}{*}{$\begin{array}{l}\text { Cell density of the } \\
\text { SRB }\end{array}$} & $1 \times 10^{4}$ cells $/ \mathrm{mL}$ & 2600 & $0.80 *$ \\
\hline & $1 \times 10^{5}$ cells $/ \mathrm{mL}$ & 2600 & $0.80 *$ \\
\hline & $1 \times 10^{6}$ cells $/ \mathrm{mL}$ & 2600 & $0.80 *$ \\
\hline \multirow{3}{*}{$\begin{array}{l}\text { Concentration of } \\
\text { sulfate }\end{array}$} & $20 \mathrm{mg} / \mathrm{L}$ & 2600 & $0.80 *$ \\
\hline & $40 \mathrm{mg} / \mathrm{L}$ & 2600 & $0.80 *$ \\
\hline & $60 \mathrm{mg} / \mathrm{L}$ & 2600 & $0.80 *$ \\
\hline \multirow{2}{*}{$\begin{array}{c}\text { Concentration of } \\
\text { ethanol }\end{array}$} & $0 \mathrm{mg} / \mathrm{L}$ & 2600 & 0.28 \\
\hline & $3 \mathrm{mg} / \mathrm{L}$ & 2600 & $0.80 *$ \\
\hline \multicolumn{4}{|c|}{ Calculation Condition } \\
\hline \multirow{4}{*}{ Grid number } & $18 \times 18$ & 2090 & $0.90 *$ \\
\hline & $24 \times 24$ & 2350 & 0.80 * \\
\hline & $30 \times 30$ & 2500 & 0.80 * \\
\hline & $36 \times 36$ & 2600 & 0.80 * \\
\hline
\end{tabular}

* Estimate value.

\section{Conclusions}

In this study, we constructed a numerical simulator estimating the oil reservoir souring induced by the injection of reservoir brine water which contained a low level of sulfate and examined the measures suppressing the reservoir souring. The following conclusions were obtained through this study:

(1) A numerical simulator which consisted of two phases (oil and water) and six components (oil, water, $\mathrm{SRB}$, sulfate, ethanol and $\mathrm{H}_{2} \mathrm{~S}$ ) was constructed in order to estimate the oil reservoir souring induced by the injection of reservoir brine water.

(2) According to the numerical simulation, it was shown that the reservoir souring was induced by the injection of the brine water whose sulfate concentration was lower than that of seawater. The production rate of $\mathrm{H}_{2} \mathrm{~S}$ associating with the production fluids was however very small, with figures such as $800 \mathrm{NmL}$ per $1 \mathrm{~kL}$ of production water.

(3) The SRB injected into the reservoir grew and generated $\mathrm{H}_{2} \mathrm{~S}$ only around the injection well whose temperature was reduced under $50^{\circ} \mathrm{C}$ in the reservoir. The most active generation of $\mathrm{H}_{2} \mathrm{~S}$ was observed in the mixing zone between the injection water and formation water, where the concentration of ethanol which was the electron donor for the sulfate reduction was higher than that in the injection water.

(4) Temperature distribution in the reservoir is the most influential factor for the $\mathrm{H}_{2} \mathrm{~S}$ generation. The injection of water whose temperature is over $50^{\circ} \mathrm{C}$ is effective for preventing $\mathrm{H}_{2} \mathrm{~S}$ generation in an oil reservoir.

(5) Both cell density of the SRB and sulfate concentration did not influence the $\mathrm{H}_{2} \mathrm{~S}$ generation caused by the SRB in the reservoir.

(6) According to our previous study, organic matters such as formate, acetate and propionate did not effect the activities of the SRB; therefore, the concentration of ethanol in the injection water 
and the reservoir brine is only influential in the $\mathrm{H}_{2} \mathrm{~S}$ generation of the SRB. Complete removal of ethanol from the injection water is effective for preventing the $\mathrm{H}_{2} \mathrm{~S}$ generation in the oil reservoir. In addition, it is important to know the correct concentration of ethanol in the formation water in the reservoir for estimating the generation of $\mathrm{H}_{2} \mathrm{~S}$ exactly.

(7) The SRB grew and generated $\mathrm{H}_{2} \mathrm{~S}$ in the low temperature area in either a homogenous or a heterogenous reservoir. The behavior of $\mathrm{H}_{2} \mathrm{~S}$ production from both reservoirs was however quite different because the flow behavior of $\mathrm{H}_{2} \mathrm{~S}$ was different between both reservoirs. Permeability heterogeneity is therefore an influential factor on the reservoir souring.

This study showed the possibility of reservoir souring induced by the brine injection under the assumption that the SRB were not affected by other metabolic groups inhabiting the reservoir brine. Because various metabolic groups inhabit oil reservoirs and they may consume or generate the organic matters which can be electron donors of SRB, the growth and metabolic activities of the SRB may be affected by them. Our next task therefore is to develop another model that considers the influence of other metabolic groups on the activities of the SRB.

Author Contributions: Y.S. and Y.O. designed the study and carried out all the numerical simulation. K.S. helped through valuable discussions. Y.S. wrote and completed the manuscript after considering the review comments provided by all authors. All authors have read and agreed to the published version of the manuscript.

Funding: This research received no external funding.

Conflicts of Interest: The authors declare no conflicts of interest.

\section{Nomenclature}

$\begin{array}{ll}\alpha & \text { Dimensional constant number } \\ c_{\mathrm{T}} & \text { Temperature coefficient term } \\ C_{\mathrm{Sulfate}} & \text { Concentration of sulfate } \\ C_{\mathrm{Ethanol}} & \text { Concentration of ethanol } \\ C_{\mathrm{Nutrient}} & \text { Concentration of the growth limiting nutrient for bacteria } \\ C_{\mathrm{SRB}} & \text { Cell density of the SRB } \\ C_{\mathrm{H} 2 \mathrm{~S}} & \text { Concentration of } \mathrm{H}_{2} \mathrm{~S} \\ k_{\mathrm{O}} & \text { Effective permeability of oil } \\ k_{\mathrm{W}} & \text { Effective permeability of water } \\ K_{\mathrm{Nutrient}} & \text { Nutrient concentration corresponding to half the maximal growth rate } \\ \mu & \text { Specific growth rate } \\ \mu_{\mathrm{m}} & \text { Maximal growth rate } \\ \mu_{\mathrm{Sulfate}} & \text { Specific growth rate including the concentration of sulfate as a variable } \\ \mu_{\mathrm{Ethanol}} & \text { Specific growth rate including the concentration of ethanol as a variable } \\ \mu_{\mathrm{SRB}} & \text { Specific growth rate of the SRB } \\ \mu_{\mathrm{O}} & \text { Oil viscosity } \\ \mu_{\mathrm{W}} & \text { Water viscosity } \\ q_{\mathrm{wi}} & \text { Injection rate of water } \\ q_{\mathrm{wp}} & \text { Production rate of water } \\ q_{\mathrm{op}} & \text { Production rate of oil } \\ \rho_{\mathrm{O}} & \text { Density of oil } \\ \rho_{\mathrm{W}} & \text { Density of water } \\ R_{\mathrm{SRB}} & \text { Growth rate of the SRB } \\ R_{\mathrm{Nutrient}} & \text { Consumption rate of a nutrient } \\ R_{\mathrm{H} 2 \mathrm{~S}} & \text { Generation rate of } \mathrm{H}_{2} \mathrm{~S} \text { by the SRB } \\ S_{0} & \text { Initial amount of sulfate } \\ S_{t} & \text { Amount of sulfate at a time } t \\ S_{\mathrm{O}} & \text { Oil saturation } \\ S_{\mathrm{w}} & \text { Water saturation } \\ t & \text { Incubation time } \\ \varphi & \text { Porosity } \\ & \end{array}$




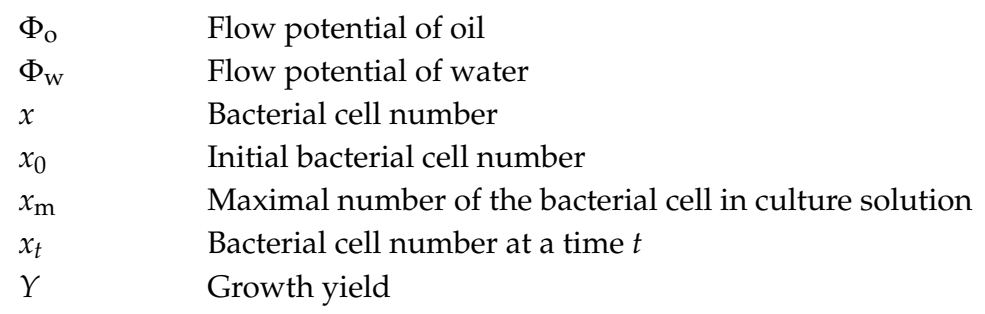

\section{References}

1. Julia, R.R.; Casey, R.J.H.; Hans, R.; Kasper, U.K.; Bo, B.J. Estimating the abundance of endospores of sulfate-reducing bacteria in environmental samples by inducing germination and exponential growth. Geomicrobiol. J. 2017, 34, 338-345.

2. Chen, C.; Shen, Y.; An, D.; Voordouw, G. Use of acetate, propionate, and butyrate for reduction of nitrate and sulfate and methanogenesis in microcosms and bioreactors simulating an oil reservoir. Appl. Environ. Microbiol. 2017, 83, e02983-16. [CrossRef]

3. Warounsak, L.; Annachhatre, A.P. Electron donors for biological sulfate reduction. Biotechnol. Adv. 2007, 25, 452-463.

4. Nagpal, S.; Chuichulcherm, S.; Livingston, A.; Peeva, L. Ethanol utilization by sulfate-reducing bacteria: An experimental and modeling study. Biotechnol. Bioeng. 2000, 70, 533-543. [CrossRef]

5. Robert, F.M.; Per, H.N. Characterization of Thermophilic Consortia from Two Souring Oil Reservoirs. Appl. Environ. Microbiol. 1996, 62, 3083-3087.

6. Voordouw, G.; Armstrong, S.M.; Reimer, M.F.; Fouts, B.; Telang, A.J.; Shen, Y.; Gevertz, D. Characterization of $16 \mathrm{~s}$ rdna genes from oil field microbial communities indicates the presence of a variety of sulfate-reducing, fermentative, and sulfide-oxidizing bacteria. Appl. Environ. Microbiol. 1996, 62, 1623-1629. [CrossRef]

7. Harada, H.; Uemura, S.; Momonoi, K. Interaction between sulfatereducing bacteria and methane-producing bacteria in uasb reactors fed with low strength wastes containing different levels of sulfate. Water Res. 1994, 28, 355-367.

8. Visser, A.; Beeksma, I.; Van Der Zee, F.; Stams, A.J.M.; Lettinga, G. Anaerobic degradation of volatile fatty acids at different sulphate concentration. Appl. Microbiol. Biotechnol. 1993, 40, 549-556. [CrossRef]

9. Okabe, S.; Characklis, W.G. Effects of temperature and phosphorous concentration on microbial sulfate reduction by Desulfovibrio desulfuricans. Biotechnol. Bioeng. 1992, 39, 1031-1042. [CrossRef]

10. Mahsan, B.; Kelly, H. Reservoir souring: Sulfur chemistry in offshore oil and gas reservoir fluids. J. Petrol. Explor. Prod. Technol. 2019, 9, 1105-1118.

11. Richard, J.J.; Benjamin, D.F.; Alexander, W.; Max, F.; Torben, L.S. Reservoir Souring—Latest developments for application and mitigation. J. Biotechnol. 2017, 256, 57-67.

12. Yevhen, H.; Jordan, M.B.; John, A.H.; Benjamin, L.H.; Blaise, M.; Ryan, J.K.; Steven, A.S.; James, A.S.; John, A.H. Understanding the souring at bakken oil reservoirs. In Proceedings of the SPE International Symposium on Oilfield Chemistry, the Woodlands, TX, USA, 11-13 April 2011; SPE-141434-MS.

13. Khatib, Z.I.; Salanitro, J.R. Reservoir souring: Analysis of surveys and experience in sour waterfloods. In Proceedings of the SPE Annual Technical Conference and Exhibition, San Antonio, TX, USA, 5-8 October 1997; SPE-38795-MS.

14. Donald, E.C.; James, F. Animal evolution, bioturbation, and the sulfate concentration of the oceans. Proc. Natl. Acad. Sci. USA 2009, 106, 8123-8127.

15. Sugai, Y.; Owaki, Y.; Sasaki, K.; Kaneko, F.; Sakai, T. Numerical modelling of the growth of sulfate-reducing bacteria indigenous to an oilfield in Japan. Petrol. Sci. Technol. 2018, 36, 1597-1604. [CrossRef]

16. Delshad, M.; Bryant, S.L.; Sepehrnoori, K.; Farhadinia, M.A. Development of a reservoir simulator for souring predictions. In Proceedings of the SPE Reservoir Simulation Symposium, Woodlands, TX, USA, 2-4 February 2009; SPE-118951-MS.

17. Farhadinia, M.A.; Bryant, S.L.; Sepehrnoori, K.; Delshad, M. Application of a 3D reservoir simulator with biodegradation capability to evaluate reservoir souring predictive models. Petrol. Sci. Technol. 2010, 28, 382-392. [CrossRef] 
18. Farhadinia, M.A.; Bryant, S.L.; Sepehrnoori, K.; Delshad, M. Development and implementation of a multidimensional reservoir souring module in a chemical flooding simulator. Petrol. Sci. Technol. 2010, 28, 534-546. [CrossRef]

19. Alexandre, G.S.; Carlos, H.V.A.; Rodrigo, R.; Marcio, C.P. Uncertainty analysis applied to biogenic reservoir souring simulation. In Proceedings of the EUROPEC/EAGE Conference and Exhibition, Amsterdam, the Netherlands, 8-11 August 2009; SPE-121175-MS.

20. Hosseininoosheri, P.; Lashgari, H.; Sepehrnoori, K. Numerical prediction of reservoir souring under the effect of temperature, ph, and salinity on the kinetics of sulfate-reducing bacteria. In Proceedings of the SPE International Conference on Oilfield Chemistry, Montgomery, TX, USA, 3-5 April 2017; SPE-184562-MS.

21. Evans, P.; Dunsmore, B. Reservoir simulation of sulphate reducing bacteria activity in the deep sub-surface. In Proceedings of the Corrosion, San Diego, CA, USA, 12-16 March 2006; NACE-06664.

22. Sunde, E.; Thorstenson, T.; Torsvik, T.; Vaag, J.E.; Espedal, M.S. Field-related mathematical model to predict and reduce reservoir souring. In Proceedings of the SPE International Symposium on Oilfield Chemistry, New Orleans, LA, USA, 2-5 March 1993; SPE-25197-MS.

23. Coombe, D.A.; Jack, T.; Voordouw, G.; Zhang, F.; Clay, B.; Miner, K. Simulation of bacterial souring control in an alberta heavy-oil reservoir. J. Can. Petrol. Technol. 2010, 49, 19-26. [CrossRef]

24. Jia, B.; Tsau, J.; Barati, R. A review of the current progress of $\mathrm{CO}_{2}$ injection EOR and carbon storage in shale oil reservoirs. Fuel 2019, 236, 404-427. [CrossRef]

25. Dunsmore, B.; Evans, P.J.; Jones, M.; Burton, S.; Lappin-Scott, H.M. When Is Reservoir Souring a Problem for Deepwater Projects? In Proceedings of the Offshore Technology Conference, Houston, TX, USA, 1-4 May 2006; OTC-18347-MS.

26. Ingvorsen, K.; Nielsen, M.Y.; Joulian, C. Kinetics of bacterial sulfate reduction in an activated sludge plant. FEMS Microbiol. Ecol. 2003, 46, 129-137. [CrossRef]

27. Sulaiman, A.Z.; Muftah, H.E.N.; Huda, A.H. Sulfate inhibition effect on sulfate reducing bacteria. J. Biochem. Tech. 2008, 1, 39-44.

28. Hallbeck, L. Determination of Sulphide Production Rates in Laboratory Cultures of the Sulphate Reducing Bacterium Desulfovibrio Aespoeensis with Lactate and H2 as Energy Sources; TR-14-14; Swedish Nuclear Fuel and Waste Management Company: Stockholm, Sweden, 2014.

29. Chen, J.; Wu, J.; Wang, P.; Zhang, D.; Chen, S.; Tan, F. Corrosion of 907 steel influenced by sulfate-reducing bacteria. J. Mater. Eng. Perform. 2019, 28, 1469-1479. [CrossRef]

30. Powell, E.O. Growth rate and generation time of bacteria, with special reference to continuous culture. J. Gen. Microbiol. 1956, 15, 492-511. [CrossRef]

31. Monod, J. The growth of bacterial cultures. Annu. Rev. Microbiol. 1949, 3, 371-394. [CrossRef]

32. Sugai, Y.; Hong, C.; Chida, T.; Enomoto, H. Simulation studies on the mechanisms and performances of MEOR using a polymer producing microorganism Clostridium sp. TU-15A. In Proceedings of the Asia Pacific Oil and Gas Conference and Exhibition, Jakarta, Indonesia, 30 October-1 November 2007; SPE-110173-MS.

33. Chen, C.; Matthew, T.B.; Kishore, K. Effect of reservoir heterogeneity on primary recovery and $\mathrm{CO}_{2}$ huff ' $n$ ' puff recovery in shale-oil reservoirs. SPE Reserv. Eval. Eng. 2014, 17, 404-413. [CrossRef]

34. Jia, B.; Tsau, J.; Barati, R. Role of molecular diffusion in heterogeneous, naturally fractured shale reservoirs during $\mathrm{CO}_{2}$ huff-n-puff. J. Petrol. Sci. Eng. 2007, 164, 31-42. [CrossRef]

(C) 2020 by the authors. Licensee MDPI, Basel, Switzerland. This article is an open access article distributed under the terms and conditions of the Creative Commons Attribution (CC BY) license (http://creativecommons.org/licenses/by/4.0/). 